\title{
Poczucie satysfakcii życiowej wśród studentów uczelni rzeszowskich
}

\section{Perception of Life Satisfaction among Students of} Rzeszów Universities

\begin{abstract}
ABSTRAKT
Satysfakcja z życia należy do najważniejszych czynników wpływaiq̨cych na subiektywne odczuwanie dobrostanu przez jednostkę. Poziom satysfakcji przekłada się na jakość rozwoju i przystosowania do nowego środowiska. Celem niniejszego artykułu jest analiza postrzegania satysfakcji z życia wśród młodych osób, którzy rozpoczęli studia na kierunkach ścisłych i humanistycznych. Badania przeprowadzono w ramach własnego projektu zrealizowanego wśród 383 studentów Politechniki Rzeszowskiej i Uniwersytetu Rzeszowskiego. Do badań wykorzystano metodę sondażu diagnostycznego, techniki kwestionariusza i standaryzowanego narzędzia badającego poziom satysfakcji z życia SWLS (Satisfaction with life scale), autorstwa Eda Dinera, Roberta A. Emmonsa, Randy'ego J. Larsena i Sharon Griffin w polskiej adaptacji Zygrfyda Juczyńskiego.

Badania ujawniły, że ogólne zadowolenie z życia studentów kształtowało się na poziomie umiarkowanym i poniżej przeciętnym. Wzięto pod uwagę następujące zmienne niezależne: uczelnia, płeć, wiek, miejsce zamieszkania, zamożność, kolejność urodzenia się w rodzinie, a także poziom osiaganych wyników w szkole średniej. W trzech przypadkach, tj. uczelnia, płeć i zamożność, satysfakcja z życia
\end{abstract}

SLOWA KLUCZOWE satysfakcja, życie, przystosowanie, studenci, uczelnie

\section{KEYWORDS}

satisfaction, life, adaptation, students, higher education

SPI Vol. 24, 2021/3

ISSN 2450-5358 e-ISSN 2450-5366 DOI: 10.12775/SPI.2021.3.008

Nadestano: 24.06 .2021 Zaakceptowano: 15.10.2021

Raporty z badań 
wśród badanych grup była na poziomie istotności statystycznej. Natomiast ogólnie satysfakcja z życia była na wyższym poziomie wśród studentów Politechniki Rzeszowskiej, także wśród badanych kobiet i osób bardziej zamożnych. Z badań wynika również, że większość badanych osób odczuwa satysfakcję z życia na poziomie umiarkowanym.

\section{ABSTRACT}

Life satisfaction is one of the most important factors influencing the subjective perception of the well-being by an individual. The level of satisfaction affects the quality of development and adaptation to the new environment. The aim of this article is to analyze the perception of life satisfaction among young people who started their studies in science and humanities. The research was carried out as part of the author's own project realized among 383 students of the Rzeszów University of Technology and the University of Rzeszów. The means employed included a diagnostic survey, the questionnaire technique and a standardized tool examining the level of satisfaction with life scale (SWLS - Satisfaction with life scale), by Ed Diner, Robert A. Emmons, Randy J. Larsen and Sharon Griffin were used in Polish adaptation by Zygrfyd Juczyński.

The research revealed that students' overall life satisfaction was moderate and below average. Independent variables were taken into account: university, gender, age, place of residence, affluence, the order in which one was born in family, as well as the level of results achieved in secondary school. In three cases, i.e. university, gender and affluence, life satisfaction was at the level of statistical significance among the studied groups. On the other hand, the overall satisfaction with life was higher in the students of the Rzeszów University of Technology, also among the surveyed women and among the wealthier students. The research also shows that most of the respondents feel satisfied with life on a moderate level.

\section{Wprowadzenie}

Człowiek jest zawsze częścią natury i wszystkie czynniki środowiskowe są w jakiś sposób związane bezpośrednio lub pośrednio z jego bytem, czyli edukacją, pracą, aktywnością, odpoczynkiem itp. Sposób bycia i wszelkie funkcje życiowe mają swoje źródło w zdrowiu, które jest siłą napędową do działania i ma także przełożenie na ludzką psychikę. Satysfakcja to przed wszystkim dobre samopoczucie, które 
wynika ze zdrowego organizmu, a także $\mathrm{z}$ możliwości zaspokajania potrzeb według hierarchii ich ważności, która jest subiektywnie przyjmowana przez każdą osobę. Satysfakcja to także pewna umiejętność wyboru tych potrzeb, które są niezbędne w danym czasie, to ich właściwa klasyfikacja na podstawie doświadczenia i wiedzy. Satysfakcja wpływa więc na sprawność utrzymania homeostazy wielu czynników, które tworzą tzw. środowisko życia jednostki.

\section{Charakterystyka satysfakcji}

Słowo „satysfakcja”, według Wielkiego stownika jezyka polskiego (https://wsjp.pl/haslo/podglad/28965/satysfakcja) pochodzi z języka łacińskiego (satisfactio) i ma dwa znaczenia: (1) zadośćuczynienie, czyli wynagrodzenie za wyrządzenie komuś krzywdy, (2) zadowolenie, czyli stan psychiczny człowieka, który osiągnął coś, na czym mu zależało, dążył do tego przez jakiś okres czasu. Również Stownik jezyka polskiego $P W N$ podobnie opisuje znaczenie terminu satysfakcja (https://sjp.pwn.pl/slowniki/satysfakcja).

Lorie Sousa i Sonja Lyubomirsky definiują satysfakcję jako zadowolenie $z$ własnego życia. Według autorek oznacza to zadowolenie z okoliczności życiowych lub ich akceptację bądź też zaspokojenie pragnień i potrzeb całego życia. Zasadniczo zadowolenie z życia jest subiektywną oceną jakości własnego życia (Sousa, Lyubomirsky 2001: 669).

Doh Chull Shin i M.D. Johnson wyjaśniają zadowolenie z życia jako ,ogólną ocenę jakości życia odniesioną do wybranych przez siebie kryteriów”. Autorzy biorą pod uwagę trzy najważniejsze komponenty: satysfakcję z życia, pozytywne uczucia i brak uczuć negatywnych (za: Kupcewicz, Szczypiński, Kędzia 2018: 28).

Jak zauważa Anna Sowińska (2014: 47), używa się w tym samym kontekście zarówno pojęcia „zadowolenie”, jak i terminu „satysfakcja”. W literaturze obydwa terminy występują często zamiennie i przez większość badaczy są traktowane jak synonimy. Autorka dostrzega element różnicujący, który charakteryzuje głównie czas występowania. Zadowolenie może być chwilowe, natomiast satysfakcję, jako „silne uczucie zadowolenia”, zazwyczaj odczuwa się po długotrwałym okresie zadowolenia. 
Zadowolenie z życia jest postrzegane jako „poznawcza” konceptualizacja szczęścia lub subiektywnego samopoczucia. Może obejmować osądy dotyczące spełnienia własnych potrzeb, celów i życzeń. Ten pogląd jest zasadniczo oparty na nowatorskich badaniach założycieli ruchu badań satysfakcji z życia. Diener i jego współpracownicy (Diener, Emmons, Larsen, Griffin, 1985; Diener, Horwitz, Emmons 1985) zdefiniowali satysfakcję z życia jako proces oceny poznawczej zależny od porównania danej sytuacji z tym, co uważa się za właściwy standard. Zatem im mniejsza rozbieżność między percepcją osiągnięć życiowych a jakimś standardem, tym większe zadowolenie z życia (Sirgy 2012: 13-14).

Cyrus S. Mirza wyjaśnia za Dienerem, Emmonsem, Larsenem i Griffin (1985) zadowolenie z życia jako ogólną miarę dobrego samopoczucia i ocenę jakości życia danej osoby zgodnie $\mathrm{z}$ wybranymi przez nią kryteriami. Satysfakcję z życia uważa się za opartą na poznawczo (racjonalnej) ocenie dobrostanu, w przeciwieństwie do pozytywnego i negatywnego afektu, który dostarcza opartej na emocjach (emocjonalnej) ocenie dobrostanu (Zika, Chamberlain 1992). Autorka także zauważa, że zarówno Cynthia Bonebright, Daniel Clay i Robert Ankenmann (2000), jak i Shnhnaz Aziz i Michael Zickar (2006) stwierdzili na podstawie badań, że pracoholicy mają znacznie mniej satysfakcji z życia niż niepracoholicy (Mirza 2012: 17-18).

Agnieszka Springer (2018: 48) wyjaśnia za Grażyną Bartkowiak, że satysfakcja jest pozytywnym, emocjonalnym nastawieniem człowieka wobec kogoś lub czegoś. To nastawienie ujawnia się w odniesieniu do jego pracy, nauki, jakichkolwiek wykonywanych zadań i czynności, jak również przy realizacji jego potrzeb, celów, wartości, a także przekonań.

Micheal Frisch wskazuje za Dienerem (2003), że dobre i pozytywne życie jest według psychologii pozytywnej czymś, co można nazwać względną przewagą szczęścia, dobrobytem, subiektywnym samopoczuciem - w przeciwieństwie do negatywnych doświadczeń afektywnych (np. lęk, depresja, złość). Autor wyjaśnia, że szczęście i satysfakcja $\mathrm{z}$ życia są związane $\mathrm{z}$ realizacją osobistych celów w dziedzinach życia, które cenimy, a także powinny być osiągane w sposób etyczny bez krzywdzenia innych oraz służyć innym w osiąganiu przez nich lepszej jakości życia (Frisch 2006: 5). 
W literaturze skoncentrowanej wokól jakości życia wiele uwagi poświęca się poczuciu subiektywnego zadowolenia z życia, tzw. dobrostanowi, pomimo różnic występujących w zakresie rozważań teoretycznych (Finogenow 2013: 346).

Uczucie zadowolenia odczuwane przy przeżywaniu satysfakcji jest swoistą rekompensatą, nagrodą za wcześniejsze poczucie niepewności i oczekiwania na osiągnięcie zamierzonego celu. Może się ono odnosić do wszystkich sfer naszego życia, przy czym należy zaznaczyć, że bardziej cenimy satysfakcję odczuwaną z racji osiągniętych celów, którym przypisujemy większe znaczenie. Obszarem bardzo cennym i o szczególnym znaczeniu dla młodego człowieka jest przede wszystkim edukacja, która poprzedza pracę zawodową (Chodkowski 2019: 108).

Zygfryd Juczyński (2001: 134) definiuje ocenę „satysfakcji z życia" jako pewien wynik świadomego porównania sytuacji jednostki ze standardami, które ona sama sobie wyznacza. W wypadku gdy wynik tego porównania zadowala jednostkę, to jego rezultatem jest odczucie przez nią satysfakcji. Tak rozumiana satysfakcja z życia stanowi przedmiot badań, które zostały zaprezentowane w niniejszym opracowaniu.

Ewa Wojtowicz (2011: 90) dostrzega istotność problemu satysfakcji. Mnogość opracowań na temat satysfakcji z życia, pracy, edukacji, rodziny przedstawiana jest w różnych kontekstach i przeważnie porównuje się ją do wielu czynników, dlatego utrudnia to dokonanie syntetycznego przeglądu badań.

Maria Finogenow (2013: 346) zauważa, że w badaniach dominuje ujęcie zadowolenia z życia w zakresie dwóch aspektów: poznawczym i afektywnym. Zadowolenie poznawcze (satysfakcja z życia) oznacza subiektywną ocenę poziomu zaspokojenia swoich aspiracji (stopień osiągnięcia celu), natomiast zadowolenie afektywne (dobrostan emocjonalny) oznacza poziom samopoczucia. Wskaźnikiem emocjonalnego dobrostanu jest wysoka częstotliwość pozytywnych doświadczeń emocjonalnych.

$\mathrm{Na}$ podstawie powyższych wyjaśnień można stwierdzić, że satysfakcja dotyczy przyjemnego stanu emocjonalnego, powstałego w wyniku pełnienia ról, wykonywania określonych czynności, urzeczywistniania swoich potrzeb, aspiracji i realizacji planów życiowych. Przyjmuje się trzy obszary tego stanu, który może przybierać różne 
nasilenie, od skrajnie negatywnego poprzez umiarkowany i skrajnie pozytywny (Korczyński 2017: 29).

$\mathrm{Na}$ potrzeby badań $\mathrm{w}$ zakresie postrzegania przez studentów pierwszego roku rzeszowskich uczelni satysfakcji z życia przyjęto definicję satysfakcji według Zygfryda Juczyńskiego (2001).

\section{Metodologia badań własnych}

Przedmiotem opracowania jest poczucie satysfakcji życiowej studentów uczelni rzeszowskich, w tym studentów nauk humanistycznych Uniwersytetu Rzeszowskiego (UR) i studentów nauk ścisłych Politechniki Rzeszowskiej (PR). Celem badania jest wzbogacenie wiedzy na temat satysfakcji i jej znaczenia w życiu młodych ludzi, którzy podjęli studia na dwóch głównych uczelniach w Rzeszowie. Warto zaznaczyć, że Skala Satysfakcji z Życia (SWLS) została opracowana w celu oceny całościowej satysfakcji z życia respondenta. Skala nie ocenia zadowolenia z poszczególnych dziedzin życia, takich jak zdrowie czy finanse, ale umożliwia badanym integrację i wagę tych dziedzin w dowolny sposób.

W nawiązaniu do tematu eksploracji sformułowano następujące problemy badawcze: Czy istnieją (a jeśli tak, to jakie) różnice $\mathrm{w}$ postrzeganiu zadowolenia $\mathrm{z}$ życia wśród studentów Uniwersytetu Rzeszowskiego i Politechniki Rzeszowskiej? Do zmiennych niezależnych zaliczono: uczelnie, płeć, wiek, miejsce zamieszkania, zamożność, kolejność urodzenia się w rodzinie, poziom osiąganych wyników w szkole średniej.

We wszystkich przypadkach przyjęto hipotezę zerową (H0), zakładającą brak istotności statystycznej w badanych grupach charakteryzujących się rozkładem normalnym. Przyjęto także przeciętny poziom odczuwanej satysfakcji w badanych grupach (5-6 sten).

Badania przeprowadzono $\mathrm{w}$ grupach studentów rozpoczynających studia na dwóch uczelniach: na kierunkach humanistycznych i na kierunkach ścisłych. Badaniami objęto 400 studentów, w tym 200 studiujących kierunki humanistyczne na Uniwersytecie Rzeszowskim i 200 osób na studiach ścisłych Politechniki Rzeszowskiej, a po weryfikacji odrzucono $17 \mathrm{z}$ powodu niekompletnych odpowiedzi. Do dalszego etapu zakwalifikowano 383 ankiet, w tym 190 respondentów realizujących wybrany kierunek humanistyczny oraz 
193 studiujących na wybranych kierunkach ścisłych. Badania przeprowadzono na obu uczelniach w czwartym kwartale 2018 roku (Chodkowski 2019: 177). Wykorzystano standaryzowaną Skalę Satysfakcji z Życia (SWLS - Satisfaction with life scale), opracowaną przez następujących autorów: Eda Dienera, Roberta A. Emmonsa, Randy'ego J. Larsena i Sharon Griffin w polskiej adaptacji Zygfryda Juczyńskiego (2001). Klasyfikacji badanych grup o zróżnicowanym poziomie satysfakcji z życia dokonano na podstawie właściwych norm stenowych, wskazując odpowiedni poziom satysfakcji z życia: wysoki (10-7 sten), przeciętny (6-5 sten) i niski (4-1 sten).

Analizę statystyczną przeprowadzono z zastosowaniem analizy wariancji ANOVA. Za istotne przyjęto prawdopodobieństwo testowe na poziomie $\mathrm{p}<0,05$, a za wysoce istotne - na poziomie p < 0,01 i p < 0,001 (Kosiba, Gacek, Bogacz-Walancik, Wojtowicz 2017: 82). Wyniki badań obliczono przy wykorzystaniu programu SPPS Statistics.

\section{Wyniki badań}

Badania przeprowadzono $\mathrm{w}$ dwóch uczelniach: Uniwersytecie Rzeszowskim i Politechnice Rzeszowskiej. Wzięto pod uwagę kierunki, na których studiuje porównywalna liczba zarówno kobiet, jak i mężczyzn.

Tabela 1. Płeć badanych według podziału na uczelnie

\begin{tabular}{|l|c|c|c|c|c|c|}
\hline \multirow{2}{*}{\multicolumn{1}{|c|}{ Uniwersytet }} & \multicolumn{7}{|c|}{ Płeć respondentów } \\
\cline { 2 - 7 } & Kobiety & $\%$ & Mężczyźni & $\%$ & Razem & $\%$ \\
\hline $\begin{array}{l}\text { Uniwersytet } \\
\text { Rzeszowski (UR) }\end{array}$ & 120 & 63,2 & 70 & 36,8 & 190 & 100 \\
\hline $\begin{array}{l}\text { Politechnika } \\
\text { Rzeszowska (PR) }\end{array}$ & 119 & 61,7 & 74 & 38,3 & 193 & 100 \\
\hline
\end{tabular}

W tabeli 1 zaprezentowano płeć respondentów według podziału na uczelnie. Kobiety zdecydowanie dominują w obu uczelniach i stanowią średnią $62,45 \%$ wszystkich badanych. 
Tabela 2. Miejsce zamieszkania respondentów według podziału na uczelnie

\begin{tabular}{|l|c|c|c|c|c|c|}
\hline \multirow{2}{*}{\multicolumn{1}{|c|}{ Uniwersytet }} & \multicolumn{6}{|c|}{ Miejsce zamieszkania } \\
\cline { 2 - 7 } & Wieś & $\%$ & Miasto & $\%$ & Razem & $\%$ \\
\hline $\begin{array}{l}\text { Uniwersytet } \\
\text { Rzeszowski (UR) }\end{array}$ & 97 & 51,1 & 93 & 48,9 & 190 & 100 \\
\hline $\begin{array}{l}\text { Politechnika } \\
\text { Rzeszowska (PR) }\end{array}$ & 122 & 63,2 & 71 & 36,8 & 193 & 100 \\
\hline
\end{tabular}

Tabela nr 2 prezentuje miejsce zamieszkiwania respondentów. Studenci z Uniwersytetu Rzeszowskiego w niewielkiej przewadze mieszkają na wsi - 51,1\%, natomiast wśród badanych z Politechniki Rzeszowskiej wartość wynosi 63,2\%.

\section{Opracowanie wyników badań własnych}

Tabela 3. Satysfakcja z życia studentów według uczelni

\begin{tabular}{|c|c|c|c|c|c|c|c|c|c|c|}
\hline \multicolumn{10}{|c|}{ Statystyki } & \multirow{2}{*}{ Sten } \\
\hline Uczelnie & $a$ & $\mathbf{N}$ & $\%$ & Suma & $M$ & SE & Me & SD & $S^{2}$ & \\
\hline UR & 797 & 190 & 49,61 & 3367,00 & 17,7211 & ,40493 & 18,0000 & 5,58163 & 31,155 & 4 \\
\hline PR & 818 & 193 & 50,39 & 3719,00 & 19,2694 &, 42350 & 20,0000 & 5,88341 & 34,615 & 5 \\
\hline \multirow[t]{3}{*}{ Ogółem } & & 383 & 100 & 7086,00 & 18,5013 & ,29536 & 19,0000 & 5,78039 & 33,413 & 5 \\
\hline & & & & \multicolumn{4}{|c|}{ ANOVA } & \multicolumn{3}{|c|}{ Miara zwiq̨zku } \\
\hline & & \multicolumn{2}{|c|}{ SS } & df & MS & $\mathbf{F}$ & $p$ & $\eta$ & $n^{2}$ & $\omega^{2}$ \\
\hline \multicolumn{2}{|c|}{ Między grupami* } & \multicolumn{2}{|c|}{229,544} & 1 & 229,544 & 6,977 &, 009 & \multirow{3}{*}{134} & \multirow{3}{*}{0,18} & \multirow{3}{*}{0,59} \\
\hline Wewnq̨irz & grupy & 1253 & , 205 & 381 & 32,898 & & & & & \\
\hline \multicolumn{2}{|c|}{ Ogółem } & \multicolumn{2}{|c|}{12763,749} & 382 & & & & & & \\
\hline
\end{tabular}

a - alfa Cronbacha, N - liczba próby, M - średnia, SE - błąd standardowej średniej, Me - mediana, SD - odchylenie standardowe, $\mathrm{SD}^{2}$ - wariancja, * - połq̨czone, SS suma kwadratów, df - stopnie swobody, MS - średni kwadrat, F - rozkład, statystyka Fishera-Snedecora, $p$ - poziom istotności, $\eta$ - eta, $\eta^{2}$ - eta kwadrat, $\omega^{2}$ - omega kwadrat

Wybór uczelni odgrywa dużą rolę w dalszym rozwoju jednostki, a przede wszystkim otwiera jej szersze perspektywy znalezienia odpowiednio płatnej pracy. Kierunki ścisłe mają w tym zakresie przewagę w porównaniu do kierunków humanistycznych. Większe możliwości rozpoczęcia kariery zawodowej i lepsze wynagrodzenie to dwa mocne 
atuty, które z pewnością przyczyniają się do większej satysfakcji z życia studentów Politechniki Rzeszowskiej. Takie spojrzenie studentów odzwierciedlają wyniki badań, które po przekształceniu na jednostki standaryzowane zostały przedstawione w skali stenowej, odpowiednio - 5 dla studentów Politechniki oraz -4 dla studentów Uniwersytetu Rzeszowskiego. Według skali SWLS w adaptacji Zygfryda Juczyńskiego (2001: 137) sten 5 oznacza poziom satysfakcji przeciętny, czyli średni, natomiast sten 4 kwalifikuje się do przedziału niskiego.

$\mathrm{Na}$ podstawie analizy wariancji wyliczonej rozkładem Fishera-Snedecora istnieje zróżnicowanie między grupami na poziomie wysokiej istotności statystycznej $\mathrm{p}<0,01$, miara związku $\eta^{2}$ wynosi 0,18 , a $\omega^{2}$ równa się 0,54. Przyjmuje się efekt o dużej sile przy 0,14 i więcej (Cohen 1988: 283-287), a także, że test jest rzetelny, ponieważ alfa Cronbacha dla obydwu grup jest większe od 0,8.

Tabela 4. Satysfakcja z życia studentów według płci

\begin{tabular}{|c|c|c|c|c|c|c|c|c|c|c|}
\hline \multicolumn{10}{|c|}{ Statystyki } & \multirow{2}{*}{ Sten } \\
\hline Płeć & $a$ & $\mathbf{N}$ & $100 \%$ & Suma & $M$ & SE & $\mathrm{Me}$ & SD & SD $^{2}$ & \\
\hline Kobiety & 810 & 239 & 62,4 & 4559,00 & 19,0753 &, 36443 & 20,0000 & 5,63402 & 31,742 & 5 \\
\hline Mężczyźni & 807 & 144 & 37,6 & 2527,00 & 17,5486 & ,49274 & 18,0000 & 5,91292 & 34,963 & 4 \\
\hline & & & & \multicolumn{4}{|c|}{ ANOVA } & \multicolumn{3}{|c|}{ Miara zwiazzku } \\
\hline & & \multicolumn{2}{|c|}{ SS } & df & MS & $\mathbf{F}$ & p & \multirow{4}{*}{\multicolumn{2}{|c|}{ 128, }} & $\omega^{2}$ \\
\hline Między gru & ami* & & 9,445 & 1 & 209,445 & 6,356 & 012 & & & \multirow{3}{*}{0,54} \\
\hline Wewnq̨irz & rupy & 125 & 54,304 & 381 & 32,951 & & & & & \\
\hline \multicolumn{2}{|c|}{ Ogółem } & \multicolumn{2}{|c|}{12763,749} & 382 & & & & & & \\
\hline
\end{tabular}

a - alfa Cronbacha, N - liczba próby, M - średnia, SE - błąd standardowej średniej, Me - mediana, SD - odchylenie standardowe, SD ${ }^{2}$ - wariancja, SS - suma kwadratów, df - stopnie swobody, MS - średni kwadrat, F-rozkład, statystyka Fishera-Snedecora, $\mathrm{p}$ - poziom istotności, $\eta$ - eta, $\eta^{2}$ - eta kwadrat, $\omega^{2}$ - omega kwadrat, ${ }^{*}$ - połqczone

Tabela 4 przedstawia wyniki porównania satysfakcji z życia studentów ze względu na ich płeć. Według różnych badań wpływ płci na zadowolenie z życia jest wieloznaczny. Na przykład Alberto Alesina, Rafael Di Tella i Robert MacCulloch wykazali, że kobiety deklarują wyższy poziom satysfakcji z życia niż mężczyźni (Alesina, Di Tella, MacCulloch 2004).

Poziom satysfakcji z życia kobiet jest na przeciętnym poziomie (sten 5) w porównaniu do mężczyzn, których wynik mieści się w przedziale niskim i wynosi w skali stenowej 4. 
$Z$ reguły mężczyźni mają wyższe od kobiet aspiracje, jeśli chodzi o uzyskanie kwalifikacji, co ułatwia im znalezienie dobrze płatnej pracy. Wyższe wynagrodzenie zapewnia większe możliwości realizacji planów osobistych, do których zaliczyć należy m.in. założenie rodziny, utrzymanie dzieci. Okres studiów ogranicza karierę zawodową i może wpływać na niski poziom odczuwania satysfakcji z życia. W przeciwieństwie do mężczyzn, kobiety zazwyczaj nie mają wygórowanych ambicji, szybciej się adaptują i są bardziej zadowolone $z$ danej sytuacji, czyli np. studiowania na uczelni. Dlatego ich poziom satysfakcji z życia mieści się w średnim przedziale i jest wyższy od mężczyzn.

Według analizy wariancji istnieje zróżnicowanie między grupami na poziomie wysokiej istotności statystycznej $\mathrm{p}<0,05$, a miara związku $\eta^{2}$ wynosi $0,16, \omega^{2}=0,54$. Jest to poziom efektu o dużej sile. Test jest rzetelny, ponieważ alfa Cronbacha przyjmuje wartości powyżej 0,8.

Tabela 5. Satysfakcja z życia studentów według wieku

\begin{tabular}{|c|c|c|c|c|c|c|c|c|c|c|}
\hline \multicolumn{10}{|c|}{ Statystyki } & \multirow[t]{2}{*}{ Sten } \\
\hline Wiek & $a$ & $\mathbf{N}$ & $100 \%$ & Suma & $M$ & SE & $\mathrm{Me}$ & SD & $S^{2}$ & \\
\hline 17 & ,838 & 3 & 0,8 & 50,00 & 16,6667 & 3,17980 & 14,0000 & 5,50757 & 30,333 & 4 \\
\hline 18 & ,793 & 21 & 5,5 & 357,00 & 17,0000 & 1,27615 & 16,0000 & 5,84808 & 34,200 & 4 \\
\hline 19 & 799 & 231 & 60,3 & 4396,00 & 19,0303 & ,36993 & 19,0000 & 5,62247 & 31,612 & 5 \\
\hline 20 & 823 & 94 & 24,5 & 1704,00 & 18,1277 & 60374 & 18,5000 & 5,85347 & 34,263 & 5 \\
\hline 21 &, 938 & 17 & 4,4 & 281,00 & 16,5294 & 1,74499 & 16,0000 & 7,19477 & 51,765 & 4 \\
\hline 22 & ,726 & 5 & 1,3 & 97,00 & 19,4000 & 2,22711 & 20,0000 & 4,97996 & 24,800 & 5 \\
\hline 23 & 671 & 6 & 1,6 & 102,00 & 17,0000 & 2,06559 & 17,0000 & 5,05964 & 25,600 & 4 \\
\hline 24 & 625 & 3 & 0,8 & 31,00 & 10,3333 & 2,40370 & 9,0000 & 4,16333 & 17,333 & 2 \\
\hline \multirow[t]{3}{*}{26 i więcej } & 750 & 3 & 0,8 & 68,00 & 22,6667 & ,33333 & 23,0000 & ,57735 & ,333 & 6 \\
\hline & & & & \multicolumn{4}{|c|}{ ANOVA } & \multicolumn{3}{|c|}{ Miara zwiqqzu } \\
\hline & & \multicolumn{2}{|c|}{ sS } & df & MS & $\mathbf{F}$ & $p$ & $\eta$ & $n^{2}$ & $\omega^{2}$ \\
\hline \multicolumn{2}{|c|}{ Między grupami* } & \multicolumn{2}{|c|}{471,058} & 8 & 58,882 & 1,791 & ,077 & \multirow{3}{*}{192} & \multirow{3}{*}{0,37} & \multirow{3}{*}{1,19} \\
\hline \multicolumn{2}{|c|}{ Wewnq̨irz grupy } & \multicolumn{2}{|c|}{12292,691} & 374 & 32,868 & & & & & \\
\hline \multicolumn{2}{|c|}{ Ogółem } & \multicolumn{2}{|c|}{12763,749} & 382 & & & & & & \\
\hline
\end{tabular}

* - połączone, N - liczba próby M - średnia, SE - błąd standardowej średniej, Me mediana, SD - odchylenie standardowe, SD $\mathrm{SD}^{2}$ - wariancja, SS - suma kwadratów, df stopnie swobody, MS - średni kwadrat, F - rozkład, statystyka Fishera-Snedecora, $\mathrm{p}$ - poziom istotności, $\eta$ - eta, $\eta^{2}$ - eta kwadrat, $\omega^{2}$ - omega kwadrat 
Wejście w dorosłość młodego człowieka jest ważnym okresem, jeśli chodzi o postrzeganie przez niego środowiska i odczuwanie satysfakcji z życia. Studia umożliwiają, a także wyrabiają umiejętności funkcjonowania $\mathrm{w}$ środowisku osób dorosłych, nawiązywania $\mathrm{z}$ nimi relacji bliższych bądź dalszych. Jest to próba radzenia sobie w życiu i swego rodzaju egzamin pokonywania problemów. Przystosowanie się do nowego środowiska zbliża młodego człowieka do samodzielności.

Kolejne badanie dotyczyło poziomu odczuwania satysfakcji z życia ze względu na wiek. Według danych z tabeli nr 5 najliczniejszą grupę stanowili respondenci w wieku 19 lat (60,3\%), a także w wieku 20 lat (24,5\%). Po przeliczeniu wyników badań, otrzymano na skali stenowej liczbę 5 , która mieści się w przedziale przeciętnego poziomu satysfakcji w obydwu grupach. Warto zaznaczyć, że studenci w wieku 26 lat i więcej $(0,8 \%)$ otrzymali w skali stenowej liczbę 6 , co przekłada się na wysoki poziom satysfakcji z życia. Natomiast osoby w wieku 24 lat $(0,8 \%)$ odczuwają satysfakcję z życia na niskim poziomie, gdyż otrzymali tylko 2 steny. Wyniki badań dotyczących ostatnich dwóch przedziałów wiekowych stanowią bardzo znikomą wartość procentową badanej populacji i z pewnością nie są wiążące w tym badaniu.

Według analizy wariancji nie istnieje zróżnicowanie między grupami na poziomie istotności statystycznej $\mathrm{p}>0,05$. Miara związku $\eta^{2}$ wynosi 0,37 , zaś $\omega^{2}=1,19$. Jest to poziom efektu o dużej sile. Test jest rzetelny, ponieważ alfa Cronbacha przyjmuje wartości powyżej 0,6.

Tabela 6. Satysfakcja z życia studentów a miejsce zamieszkania

\begin{tabular}{|c|c|c|c|c|c|c|c|c|c|c|}
\hline \multicolumn{7}{|c|}{ Statystyki } & Sten \\
$\begin{array}{c}\text { Mamiejsce } \\
\text { zamieszania }\end{array}$ & a & N & $100 \%$ & Suma & M & SE & Me & SD & SD $^{2}$ & Stes \\
\hline Wieś &, 818 & 219 & 57,5 & 4077,00 & 18,6164 &, 38345 & 19,0000 & 5,67458 & 32,201 & 5 \\
\hline $\begin{array}{c}\text { Małe miasto } \\
\text { do 20 tys. }\end{array}$ &, 800 & 67 & 18,0 & 1277,00 & 18,9851 &, 71853 & 19,0000 & 5,88138 & 34,591 & 5 \\
\hline $\begin{array}{c}\text { Średnie } \\
\text { miasto } \\
\text { 20-100 tys. }\end{array}$ & 799 & 53 & 14,3 & 1013,00 & 19,1132 &, 79396 & 20,0000 & 5,78014 & 33,410 & 5 \\
\hline $\begin{array}{c}\text { Duże miasto } \\
\text { pow. 100 } \\
\text { tys. }\end{array}$ &, 802 & 44 & 10,2 & 724,00 & 18,5013 &, 89067 & 16,0000 & 5,90803 & 33,413 & 5 \\
\hline
\end{tabular}




\begin{tabular}{|c|c|c|c|c|c|c|c|c|}
\hline & & \multicolumn{4}{|c|}{ ANOVA } & \multicolumn{3}{|c|}{ Miara zwiqqzku } \\
\hline & SS & df & MS & $\mathbf{F}$ & $\mathbf{p}$ & $n$ & $\eta^{2}$ & $\omega^{2}$ \\
\hline Między grupami* & 222,754 & 3 & 74,251 & 2,244 & 083 & \multirow{3}{*}{132} & \multirow{3}{*}{,017 } & \multirow{3}{*}{0,57} \\
\hline Wewnq̨trz grupy & 12540,996 & 379 & 33,090 & & & & & \\
\hline Ogółem & 12763,749 & 382 & & & & & & \\
\hline
\end{tabular}

* - połq̨czone, N - liczba próby M - średnia, SE - błąd standardowej średniej, Me mediana, SD - odchylenie standardowe, $\mathrm{SD}^{2}$ - wariancja, SS - suma kwadratów, df stopnie swobody, MS - średni kwadrat, F - rozkład, statystyka Fishera-Snedecora, $p$ - poziom istotności, $\eta$ - eta, $\eta^{2}$ - eta kwadrat, $\omega^{2}$ - omega kwadrat

Miejsce zamieszkania stanowi ważny czynnik w funkcjonowaniu człowieka. Przekłada się to na dostęp do całej infrastruktury edukacyjnej, jej bliskości i wielowymiarowości. Możliwości rozwoju są więc zdecydowanie lepsze dla osób zamieszkałych w obszarze miejskim. Jakkolwiek ostatnie lata wskazują na pewne zrównoważenie za sprawą technologii informacyjno-komunikacyjnych, które przyczyniają się do wyrównywania szans w edukacji i rozwoju wśród osób zamieszkałych w różnych miejscach, a zwłaszcza na wsi. W kolejnym badaniu sprawdzono poziom satysfakcji z życia między respondentami mieszkającymi w obszarach wiejskim i miejskim. Na podstawie wyników badań stwierdzono przeciętny poziom satysfakcji w obydwu grupach, która na skali stenowej odpowiada cyfrze 5. Według obliczeń wariancji wyliczonej rozkładem Fishera-Snedecora, nie istnieje zróżnicowanie między grupami na poziomie istotności statystycznej, gdyż p > 0,05.

Miara związku $\eta^{2}$ wynosi $0,17, \omega^{2}=0,57$. Jest to poziom efektu o dużej sile. Test jest rzetelny, ponieważ alfa Cronbacha przyjmuje wartości powyżej 0,7, czyli występuje wewnętrzna spójność kwestionariusza.

Tabela 7. Satysfakcja z życia studentów a ich zamożność

\begin{tabular}{|c|c|c|c|c|c|c|c|c|c|c|}
\hline \multicolumn{10}{|c|}{ Statystyki } & \\
\hline Zamożność & $a$ & N & $100 \%$ & Suma & M & SE & Me & SD & SD $^{2}$ & Sten \\
\hline Zamożna & 797 & 44 & $11,5 \%$ & 894,00 & 20,3182 &, 90147 & 20,5000 & 5,97970 & 35,757 & 5 \\
\hline Przeciętna &, 807 & 321 & $83,8 \%$ & 5948,00 & 18,5296 &, 31301 & 19,0000 & 5,60802 & 31,450 & 5 \\
\hline $\begin{array}{c}\text { Poniżej } \\
\text { przeciętnei }\end{array}$ &, 803 & 18 & $4,7 \%$ & 244,00 & 13,5556 & 1,37252 & 12,0000 & 5,82310 & 33,908 & 3 \\
\hline
\end{tabular}




\begin{tabular}{|c|c|c|c|c|c|c|c|c|}
\hline & & \multicolumn{4}{|c|}{ ANOVA } & \multicolumn{3}{|c|}{ Miara zwiqzzku } \\
\hline & SS & df & MS & $\mathbf{F}$ & $\mathbf{p}$ & $\eta$ & $\eta^{2}$ & $\omega^{2}$ \\
\hline $\begin{array}{c}\text { Między } \\
\text { grupami* }\end{array}$ & 585,791 & 2 & 292,895 & 9,139 &, 000 & \multirow{3}{*}{ 214 } & \multirow{3}{*}{0,46} & \multirow{3}{*}{1,46} \\
\hline Wewnqqtrz grupy & 12177,959 & 380 & 32,047 & & & & & \\
\hline Ogółem & 12763,749 & 382 & & & & & & \\
\hline
\end{tabular}

* - połączone, $\mathrm{N}$ - liczba próby $\mathrm{M}$ - średnia, SE - błąd standardowej średniej, Me mediana, SD - odchylenie standardowe, SD2 - wariancja, SS - suma kwadratów, df stopnie swobody, MS - średni kwadrat, F - rozkład, statystyka Fishera-Snedecora, $\mathrm{p}$ - poziom istotności, $\eta$ - eta, $\eta^{2}$ - eta kwadrat, $\omega^{2}$ - omega kwadrat

Uwarunkowania ekonomiczne należą do ważnych czynników funkcjonowania wszystkich członków rodziny. Przyczyniają się niewątpliwie do prawidłowego rozwoju, wychowania i edukacji dzieci. Rodzice mogą zaspokajać potrzeby swoje i dzieci, a także dbać o rozwój wszystkich członków w rodzinie.

Następne badanie, którego wyniki przedstawiono w tabeli nr 7, wskazuje na odczucie satysfakcji ze względu na zamożność i potwierdza wcześniejsze rozważania.

W tym badaniu wzięto pod uwagę trzy zakresy: rodzina zamożna, przeciętna i poniżej przeciętnej. Najliczniejszą grupę stanowili respondenci z rodzin o przeciętnej zamożności (83,8\%). Z rodzin zamożnych wywodziło się $11,5 \%$ badanych, a rodzin na poziomie ekonomicznym poniżej przeciętnej-4,7\%. Badani z dwóch pierwszych grup respondentów odczuwają satysfakcję z życia na przeciętnym poziomie, w skali stenowej jest to 5 . Natomiast studenci $\mathrm{z}$ trzeciej grupy odczuwają satysfakcję z życia na niskim poziomie, co odzwierciedla liczba 3 na skali stenowej.

$\mathrm{Na}$ podstawie analizy wariancji wyliczonej rozkładem Fishera-Snedecora zauważono, że istnieje zróżnicowanie między grupami na wysokim poziomie istotności statystycznej: $\mathrm{p}<0,01$, a miara związku $\eta^{2}$ wynosi $0,46, \omega^{2}=1,46$ - jest to na poziomie bardzo silnego efektu. Alfa Cronfacha jest powyżej 0,7 co oznacza, że test jest rzetelny. 
Tabela 8. Satysfakcja z życia studentów w zależności od kolejności urodzenia się

\begin{tabular}{|c|c|c|c|c|c|c|c|c|c|c|}
\hline \multicolumn{10}{|c|}{ Statystyki } & \multirow[b]{2}{*}{ Sten } \\
\hline $\begin{array}{l}\text { Kolejność } \\
\text { urodzenia }\end{array}$ & a & $\mathbf{N}$ & $100 \%$ & Suma & $M$ & SE & $\mathrm{Me}$ & SD & $S^{2}$ & \\
\hline Jedynak & ,781 & 48 & 12,5 & 939,00 & 19,5625 & 81045 & 20,0000 & 5,61497 & 31,528 & 5 \\
\hline Najstarszy & 809 & 143 & 37,3 & 2652,00 & 18,5455 & ,49150 & 19,0000 & 5,87754 & 34,545 & 5 \\
\hline Najmłodszy & ,829 & 131 & 34,2 & 2410,00 & 18,3969 &, 50734 & 18,0000 & 5,80673 & 33,718 & 5 \\
\hline Średni & ,794 & 61 & 15,9 & 1085,00 & 17,7869 & ,72168 & 19,0000 & 5,63653 & 31,770 & 4 \\
\hline & & & & \multicolumn{4}{|c|}{ ANOVA } & \multicolumn{3}{|c|}{ Miara zwiqzzku } \\
\hline & \multicolumn{3}{|c|}{ SS } & df & MS & $\mathbf{F}$ & $\mathbf{p}$ & $n$ & $\eta^{2}$ & $\omega^{2}$ \\
\hline $\begin{array}{c}\text { Między } \\
\text { grupami* }\end{array}$ & \multicolumn{3}{|c|}{86,894} & 3 & 28,965 & 866 & 459 & \multirow{3}{*}{,083 } & \multirow{3}{*}{,007 } & \multirow{3}{*}{0,22} \\
\hline $\begin{array}{l}\text { Wewnqtiz } \\
\text { grupy }\end{array}$ & \multicolumn{3}{|c|}{12676,855} & 379 & 33,448 & & & & & \\
\hline Ogółem & \multicolumn{3}{|c|}{12763,749} & 382 & & & & & & \\
\hline
\end{tabular}

* - połączone, N - liczba próby M - średnia, SE - błąd standardowej średniej, Me mediana, SD - odchylenie standardowe, $\mathrm{SD}^{2}$ - wariancja, SS - suma kwadratów, df stopnie swobody, MS - średni kwadrat, F - rozkład, statystyka Fishera-Snedecora, $p$ - poziom istotności, $\eta$ - eta, $\eta^{2}$ - eta kwadrat, $\omega^{2}$ - omega kwadrat

Na poziom satysfakcji może również wpływać to, którym z kolei dzieckiem jest się w rodzinie. Najstarsze dziecko zwykle przeciera ścieżkę jako pierwsze w wielu wydarzeniach szkolnych, domowych. $\mathrm{Na}$ pewno jest to ciekawsze doświadczenie niż powielanie po jakimś czasie tych samych aktywności przez młodszych członków rodziny. Natomiast młodsze rodzeństwo może być faworyzowane przez rodziców. Często też się zdarza, że starszemu dziecku zleca się opiekę nad młodszym, np. w czasie nieobecności rodziców. To tylko nieliczne przykłady, które pokazują, że na odczuwany poziom satysfakcji może wpływać wiek i kolejność urodzenia się dziecka w rodzinie. W badaniu przyjęto, że dziecko może być najstarsze, średnie, najmłodsze lub też może być jedynakiem. $Z$ danych w tabeli $n r$ wynika, że poziom przeciętny odczuwanej satysfakcji z życia mają osoby urodzone jako jedynacy, najstarsi i najmłodsi. Po przeliczeniu na steny jest to wartość nr 5. Warto zaznaczyć, że najwięcej badanych znajdowało się w przedziale najstarszy $-37,3 \%$ i najmłodszy $-34,2 \%$. W przeciwieństwie do tych grup niskie poczucie satysfakcji z życia mają respondenci urodzeni jako średni $(15,9 \%)$. Po przeliczeniu na skalę stenową jest to cyfra 4 . 
$\mathrm{Na}$ podstawie analizy wariancji wyliczonej rozkładem Fishera-Snedecora w tym badaniu nie istnieje zróżnicowanie między grupami na poziomie istotności statystycznej $-\mathrm{p}>0,05$. Test jest rzetelny, ponieważ alfa Cronbacha wynosi powyżej 0,7 .

Tabela 9. Satysfakcja z życia studentów a poziom osiqganych wyników w szkole średniej

\begin{tabular}{|c|c|c|c|c|c|c|c|c|c|c|}
\hline \multicolumn{10}{|c|}{ Statystyki } & \multirow[b]{2}{*}{ Sten } \\
\hline $\begin{array}{l}\text { Zaliczanie się } \\
\text { do uczniów }\end{array}$ & $a$ & $\mathbf{N}$ & $100 \%$ & Suma & M & SE & Me & SD & $S^{2}$ & \\
\hline $\begin{array}{c}\text { Stabych, } \\
\text { ale nie } \\
\text { najsłabszych }\end{array}$ & ,731 & 10 & 2,6 & 172,00 & 17,2000 & 1,40475 & 16,5000 & 4,44222 & 19,733 & 4 \\
\hline Przeciętnych & 810 & 96 & 25,1 & 1664,00 & 17,3333 & ,57137 & 17,5000 & 5,59825 & 31,340 & 4 \\
\hline $\begin{array}{c}\text { Dobrych, ale } \\
\text { nie najlepszych }\end{array}$ & ,794 & 213 & 55,6 & 4036,00 & 18,9484 & ,38180 & 20,0000 & 5,57218 & 31,049 & 5 \\
\hline \multirow[t]{3}{*}{ Najlepszych } & 848 & 64 & 16,7 & 1214,00 & 18,9688 & ,83659 & 19,0000 & 6,69273 & 44,793 & 5 \\
\hline & & & & \multicolumn{4}{|c|}{ ANOVA } & \multicolumn{3}{|c|}{ Miara związku } \\
\hline & \multicolumn{3}{|c|}{ SS } & df & MS & $\mathbf{F}$ & $\mathbf{p}$ & $\eta$ & $\eta^{2}$ & $\omega^{2}$ \\
\hline $\begin{array}{l}\text { Między } \\
\text { grupami* }\end{array}$ & \multicolumn{3}{|c|}{204,447} & 3 & 68,149 & 2,057 & 106 & \multirow{3}{*}{, 127 } & \multirow{3}{*}{, 016} & \multirow{3}{*}{0,52} \\
\hline $\begin{array}{l}\text { Wewnątrz } \\
\text { grupy }\end{array}$ & \multicolumn{3}{|c|}{12559,303} & 379 & 33,138 & & & & & \\
\hline Ogółem & \multicolumn{3}{|c|}{12763,749} & 382 & & & & & & \\
\hline
\end{tabular}

* - połączone, N - liczba próby, M - średnia, SE - błąd standardowej średniej, Me Mediana, SD - odchylenie standardowe, SD ${ }^{2}$ - wariancja, SS - suma kwadratów, df stopnie swobody, MS - średni kwadrat, F - rozkład, statystyka Fishera-Snedecora, $\mathrm{p}$ - poziom istotności, $\eta$ - eta, $\eta^{2}$ - eta kwadrat, $\omega^{2}$ - omega kwadrat

Tabela nr 9 przedstawia wyniki badań dotyczące satysfakcji z życia studentów pod względem uzyskanych ocen w szkole średniej. Studenci zaliczający się do przedziału uczniów dobrych $(55,6 \%)$ i najlepszych (16,7\%) odczuwają satysfakcję w zakresie średnim, czyli przeciętnym, co po przeliczeniu na steny daje liczbę 5 . Natomiast respondenci, którzy należeli do grupy uczniów słabych $(2,6 \%)$ i przeciętnych $(25,1 \%)$, odczuwają satysfakcję na poziomie niskim. Poziom ten po przeliczeniu odzwierciedla liczba 4 na skali stenowej. Wynika stąd, że respondenci będący dobrymi uczniami w szkole średniej odczuwają wyższą satysfakcję z życia w porównaniu do respondentów, 
którzy byli uczniami słabymi. Na podstawie analizy wariancji i rozkładu statystyki Fishera-Snedecora wyniki między czterema grupami nie wykazują istotności statystycznej, gdyż $\mathrm{p}>0,05$. W tym przypadku test jest również rzetelny, ponieważ alfa Cronbacha wynosi powyżej 0,7 .

\section{Konkluzje}

Satysfakcja należy do ważnych czynników, które mają przełożenie na dobrostan psychiczny i fizyczny człowieka. Satysfakcja na poziomie wysokim przyczynia się do lepszego funkcjonowania jednostki. Wówczas wykazuje ona większą motywację, która wzmacnia optymizm i wyzwala większą energię do codziennej aktywności. Natomiast odczuwanie satysfakcji na niskim poziomie powoduje u człowieka różne frustracje, brak motywacji i odpowiedniej energii do działania, a także wpływa w zasadniczy sposób na zwiększenie stopnia pesymizmu.

Badania miały na celu sprawdzenie poziomu satysfakcji z życia wśród studentów nauk humanistycznych Uniwersytetu Rzeszowskiego i studentów nauk ścisłych Politechniki Rzeszowskiej. Chcąc lepiej zrozumieć satysfakcję z życia, do badań przyjęto definicję satysfakcji według Juczyńskiego (2001: 134). Wzięto pod uwagę następujące zmienne niezależne według: uczelnia, płeć, wiek, miejsce zamieszkania, zamożność, kolejność urodzenia się w rodzinie, a także osiągane wyniki w szkole średniej.

$\mathrm{Na}$ podstawie przeprowadzonych obliczeń wykazano, że istnieje zróżnicowanie w poziomie istotności statystycznej w zależności od uczelni (tabela 3), płci (tabela 4) i zamożności (tabela 7), gdzie $\mathrm{p}<0,05$.

Wyniki badań (tabela 3) pozwalają stwierdzić, że występuje różnica między badanymi grupami w wysokim poziomie istotności statystycznej, co świadczy o silnym efekcie. Natomiast studenci z Politechniki Rzeszowski przejawiają wyższy poziom satysfakcji z życia (sten 5) w przeciwieństwie do studentów z Uniwersytetu Rzeszowskiego (sten 4).

Wyniki badań według kryterium płci (tabela 4) ujawniły, że wyższy poziom satysfakcji z życia posiadają kobiety (sten 5) przeciwieństwie do mężczyzn (sten 4). Na podstawie obliczeń wariancji 
zróżnicowanie według płci jest istotne statystycznie $(\mathrm{p}<0,05)$, a miara związku $\eta^{2}$ stanowi o poziomie bardzo silnego efektu.

Kolejne badanie według kryterium zamożności wykazało zróżnicowanie na poziomie wysokiej istotności statystycznej $(\mathrm{p}<0,01)$, co również stanowi o poziomie bardzo silnego efektu. Respondenci pochodzący z rodzin zamożnych i przeciętnie sytuowanych odczuwają satysfakcję życia na poziomie przeciętnym (sten 5), natomiast studenci z rodzin o sytuacji materialnej poniżej przeciętnej odczuwają satysfakcję na niskim poziomie (sten 3).

W pozostałych wyliczeniach przeprowadzonych za pomocą analizy wariancji ANOVA, dotyczących następujących zmiennych niezależnych: wieku, miejsca zamieszkania, kolejności urodzenia się $\mathrm{w}$ rodzinie i poziomu osiąganych wyników w szkole średniej nie stwierdzono zróżnicowania na poziomie istotności statystycznej $(\mathrm{p}>0,05)$.

W przypadku odczuwania satysfakcji życia $\mathrm{w}$ tabeli 5 zaprezentowano podział ze względu na wiek. Największa liczba badanych respondentów plasowała się w przedziale wiekowym 19-20 lat $(84,8 \%)$. W tej grupie satysfakcję z życia określono na poziomie przeciętnym (sten 5). 0,8\% respondentów w wieku 24 lat (sten 2) odczuwa satysfakcję na bardzo niskim poziomie, natomiast $0,8 \%$ respondentów w wieku 26 lat i więcej odczuwa satysfakcję na wysokim poziomie (sten 6 ). W pozostałych przedziałach wiekowych: 17 , 18, 21 i 23 lat satysfakcja życia jest na przeciętnym poziomie (sten 4).

W tabeli 6 przedstawiono wyniki badań według kryterium miejsca zamieszkania. Wynika z nich, że respondenci mieszkający zarówno w obszarach wiejskich, jak i miejskich odczuwają satysfakcję z życia na przeciętnym poziomie i w skali stenowej jest to liczba 5 .

Satysfakcja $\mathrm{z}$ życia $\mathrm{w}$ zależności od kolejności urodzenia się $\mathrm{w}$ rodzinie (tabela 8) jest na poziomie przeciętnym u jedynaków, dzieci najstarszych i najmłodszych (sten 5). Natomiast u respondentów, którzy mają młodsze i starsze rodzeństwo, satysfakcja z życia jest na poziomie niskim (sten 4).

W przypadku zmiennej niezależnej, jaką są wyniki osiągane w szkole średniej (tabela 9), satysfakcja z życia jest na poziomie przeciętnym u tych respondentów, którzy zaliczali się do uczniów najlepszych, a także dobrych, ale nienajlepszych (sten 5). Natomiast 
satysfakcja jest na poziomie niskim u studentów, którzy zaliczali się do uczniów przeciętnych i słabych, ale nie najsłabszych (sten 4).

Zoriana Sprynska i jej współpracownicy stwierdzają za Augustynem Bańką (2005), że „zadowolenie z życia nie jest prostą pochodną obiektywnych warunków życia, ale związane jest między innymi z subiektywnym nadawaniem znaczenia zdarzeniom i doświadczeniom, które stają się udziałem jednostki. Istotne w tym aspekcie są także procesy socjalizacji oraz zmiany rozwojowe związane $\mathrm{z}$ wiekiem wyłaniającej się dorosłości, które sprzyjają odczuwaniu satysfakcji z życia" (Sprynska, Tychmanowicz, Filipiak 2019: 74-75).

Należy zaznaczyć, że wiele badań dotyczących problemu satysfakcji przedstawianych jest w różnych kontekstach. Przeważnie też satysfakcję uzależnia się od wielu czynników. Autorzy koncentrują się na sprawdzeniu korelacji między wybranymi zmiennymi i ewentualnym występowaniu pomiędzy nimi związków, dlatego utrudnia to dokonanie syntetycznego przeglądu badań pod względem tylko postrzegania satysfakcji (Wojtowicz 2011: 90).

W podsumowaniu badań nasuwają się następujące wnioski. Ponad połowa badanych studentów odczuwa satysfakcję z życia na poziomie przeciętnym (50,39\%), nieco mniejsza liczba (49,61\%) wskazuje na niski poziom satysfakcji. Budzi to pewien niepokój dotyczący przyjmowania niewłaściwych postaw prożyciowych przez dorastającą młodzież. Wynika z tego również, że wielu młodych ludzi ma problemy z wyznaczaniem sobie standardów życiowych i ich realizacją. Odzwierciedlają to wyniki badań w zakresie motywacji do podjęcia studiów, w których wpływ doradcy zawodowego nie miał zupełnie znaczenia - uzyskane odpowiedzi wyniosły powyżej 84\%, i to zarówno wśród kobiet, jak i mężczyzn (Chodkowski 2021: 136).

Przeciętny i niski poziom satysfakcji $\mathrm{z}$ życia $\mathrm{w}$ grupie studentów obu uczelni stanowi zatem wyzwanie dla edukacji, nawet na poziomie niższym niż akademicki. Zoriana Sprynska i współpracownicy (2019: 75) w swoim opracowaniu badań sugerują np. treningi w zakresie przeformułowywania niepowodzeń, pozytywnego wartościowania posiadanych kompetencji i zasobów.

Należy przypomnieć, że współczesne czasy charakteryzują się szerokim wykorzystaniem technologii informacyjno-komunikacyjnych, które umożliwiają studentom lepszy dostęp do wiedzy i systematyczne jej wzbogacanie. Oprócz tego studenci mają dużo 
szersze możliwości rozwoju swoich pasji, zainteresowań i właściwego wykorzystania posiadanych uzdolnień. $\mathrm{W}$ przypadku występowania problemów ze znalezieniem pracy studenci bądź absolwenci mogą zmienić swoje kwalifikacje dzięki szerokim ofertom szkoleniowym, kursom czy studiom podyplomowym.

Poziom odczuwania satysfakcji z życia jest ważnym czynnikiem, który znacząco oddziałuje na funkcjonowanie człowieka. Satysfakcja bowiem wpływa na motywację do działania, a to $z$ kolei przekłada się na wielostronny rozwój jednostki, a także szybsze i lepsze jej przystosowanie do nowego środowiska życia. W przypadku studentów jest to o tyle ważne, że ma to przełożenie bezpośrednio na wyższą uczelnię, która przejmuje odpowiedzialność za kształcenie młodego człowieka i właściwe przygotowanie go do przyszłej pracy zawodowej i funkcjonowania w społeczeństwie.

Zoran Mihanović i jego wspólpracownicy (2016) wymieniają za Jacqueline Douglas, Alexem Douglasem i Barrym Barnesem (2006) cztery główne powody, dla których konieczne jest przyjrzenie się opiniom, oczekiwaniom i satysfakcji uczniów/studentów. Są nimi: (1) umożliwienie wypowiedzenia się przez samych studentów na temat sytuacji, jaka jest na uczelni, co powinno zastać wykorzystane w ulepszaniu usług szkolnictwa wyższego; (2) zachęcanie uczniów do refleksji nad procesem zdobywania wiedzy; (3) umożliwienie instytucjom edukacyjnym określenia kryteriów jakości i stworzenia wskaźników, które mogą wpłynąć na reputację ich instytucji na rynku; (4) umożliwienie studentom wyrażenia zadowolenia $\mathrm{z}$ ich doświadczenia akademickiego.

Mając powyższe na uwadze, wskazane jest prowadzenie dalszych badań, które mogą się okazać pomocne dla specjalistów, np. doradców zawodowych, pedagogów, psychologów. Badania takie mogłyby lepiej zdiagnozować i zweryfikować postawy studentów, np. wobec nastawienia do życia osobistego, studiów i planów zawodowych. Badaniami powinny być zainteresowane także same uczelnie, na których spoczywa obowiązek nieustannego dostosowywania swojej oferty edukacyjnej do potrzeb zmieniającego się rynku pracy. 


\section{Bibliografia}

Alesina A., Di Tella R., MacCulloch R. (2004). Inequality and Happiness: Are Europeans and Americans Different?, "Journal of Public Economics”, t. 88, nr 9-10, s. 2009-2042.

Aziz S., Zickar M.J. (2006). A Cluster Analysis Investigation of Workaholism as a Syndrome, „Journal of Occupational Health Psychology”, t. 11, nr 1, s. $52-62$.

Bańka A. (2005). Jakość życia a jakość rozwoju. Spoteczny kontekst ptci, aktywności i rodziny, [w:] Psychologia jakości życia, red. A. Bańka, Poznań: Stowarzyszenie Psychologia i Architektura, s. 11-78.

Bartkowiak G. (2009). Cztowiek w pracy. Od stresu do sukcesu w organizacji, Warszawa: Polskie Wydawnictwo Ekonomiczne.

Bonebright C.A., Clay D.L., Ankenmann R.D. (2000). The Relationship of Workaholism with Work-Life Conflict, Life Satisfaction, and Purpose in Life, "Journal of Counseling Psychology”, t. 47, nr 4, s. 469-477.

Chodkowski Z. (2019). Adaptacja cztowieka do środowiska pracy, Rzeszów: Wydawnictwo Uniwersytetu Rzeszowskiego.

Chodkowski Z. (2021). Wptyw środowiska na motywację do wyboru studiów przez studentów rzeszowskich uczelni, „Przedsiębiorczość - Edukacja”, t. 17 , nr 1, s. 126-139.

Cohen J. (1988). Statistical Power Analysis for Behavioral Sciences, $2^{\text {nd }}$ ed. Hillsdale (NJ): Erlbaum.

Diener E., Emmons R.A., Larsen R.J., Griffin S. (1985). The Satisfaction with Life Scale, „Journal of Personality Assessment”, t. 49, nr 1, s. 71-75.

Diener E., Horwitz F., Emmons R.A. (1985). Happiness of the Very Wealthy, „Social Indicators Research”, t. 16, s. 263-274.

Douglas J., Douglas A., Barnes B. (2006). Measuring Student Satisfaction at a UK University, „Quality Assurance in Education”, t. 14, $\mathrm{nr} 3$, s. 251-267.

Finogenow M. (2013). Poczucie koherencji a satysfakcja z życia $i$ dobrostan emocjonalny osób w wieku emerytalnym, „Psychologia Społeczna”, t. 8, nr 3(26), s. 346-353.

Frisch M.B. (2006). Quality of Life Therapy: Applying a Life Satisfaction Approach to Positive Psychology and Cognitive Therapy, Hoboken (NJ): John Wiley \& Sons.

Juczyński Z. (2001). Narzędzia pomiaru w promocji i psychologii zdrowia, Warszawa: Pracownia Testów Psychologicznych Polskiego Towarzystwa Psychologicznego.

Korczyński S. (2017). Satysfakcja zawodowa nauczycieli, Łódź: Wydawnictwo Akademii Humanistyczno-Ekonomicznej w Eodzi.

Kosiba G., Gacek M., Bogacz-Walancik A., Wojtowicz A. (2017). Zachowania prozdrowotne a satysfakcja z życia studentów kierunków nauczycielskich, „Teraźniejszość - Człowiek - Edukacja”, t. 20, nr 2(78), s. 79-93. 
Mirza C.M. (2012). Positive and Negative Workaholism: An Abstract of a Thesis Presented to The Faculty of the Department of Psychology University of Houston, https://uh-ir.tdl.org/bitstream/handle/10657/ETD-UH-2012-05-355/MIRZA-.pdf.

Kupcewicz E., Szczypiński W., Kędzia A. (2018). Satysfakcja z życia w kontekście życia zawodowego pielęgniarek, „Pielęgniarstwo i Zdrowie Publiczne" t. 8, nr 1, s. 27-32.

Shin D.C.,Johnson D.M. (1978).Avowed Happiness as an Overall Assessment of the Quality of Life, „Social Indicators Research”, t. 5, nr 1, s. 475-492.

Mihanović Z., Batinić A.B., Pavičić J. (2016). The Link Between Students' Satisfaction with Faculty, Overall Students' Satisfaction with Students Life and Student Performances, „Review of Innovation and Competitiveness”, t. 2, nr 1, s. 37-60.

„Satysfakcja” [hasło], [w;], Stownik jezyka polskiego, Warszawa: Wydawnictwo PWN, https://sjp.pwn.p1/sjp/satysfakcja;2574915.

„Satysfakcja” [hasło], [w;], Wielki stownik jezyka polskiego, Warszawa: Instytut Języka Polskiego PAN, https://wsjp.pl/haslo/podglad/28965/ satysfakcja.

Sirgy M.J. (2012). The Psychology of Quality of Life: Hedonic Well-Being, Life Satisfaction, and Eudaimonia, Dordrecht-New York: Springer.

Sousa L., Lyubomirsky S. (2001). Life Satisfaction, [w:] Encylopedia of Women and Gender: Sex Similarities and Differences and the Impact of Society on Gender, t. 2, red.J. Worell, San Diego (CA): Academic Press, s. 667-676, https://www.researchgate.net/publication/284318649_Life_satisfaction.

Sowińska A. (2018). Zadowolenie z pracy-problemy definicyjne, „Studia Ekonomiczne", nr 197, s. 45-56.

Springer A. (2018). Kompetencje i satysfakcja. Identyfikacja, ocena i znaczenie dopasowania, Warszawa: Difin.

Sprynska Z., Tychmanowicz A., Filipiak S. (2019). Kto jest szczęśliwszy? Optymizm, wartości i satysfakcja z życia studentów polskich i ukraińskich, „Czasopismo Psychologiczne - Psychological Journal”, t. 25, nr 1, s. 69-77.

Wojtowicz E. (2011). Cele życiowe oraz koncepcje cech, a satysfakcja z pierwszej pracy kobiet i mężczyzn, „Problemy Profesjologii”, nr 2, s. 89-95.

Zika S., Chamberlain K. (1992). On the Relation Between Meaning in Life and Psychological Well-Being, „British Journal of Psychology”, t. 83, nr 1, s. 133-145.

\title{
ADRES DO KORESPONDENCJI
}

\author{
Dr Zbigniew Chodkowski \\ Uniwersytet Rzeszowski \\ Instytut Pedagogiki \\ e-mail: zchodkowski@ur.edu.pl
}

